\title{
Density effect and economic threshold of Japanese brome (Bromus japonicus Houtt.) in wheat
}

\author{
Qi Li ${ }^{1}$, Long Du ${ }^{1}$, Guohui Yuan ${ }^{1}$, Wenlei Guo ${ }^{1}$, Wei $\mathrm{Li}^{1}$, and Jinxin Wang ${ }^{1 *}$
}

\section{ABSTRACT}

Japanese brome (Bromus japonicus Houtt.) is a winter annual weed commonly found in the wheat (Triticum aestivum L.) fields of China. It is prevalent in northern China and produces obvious wheat yield losses. Information on the interference of Japanese brome on wheat density and its economic threshold (ET) is unknown; this information is useful to manage Japanese brome. Twoyear field experiments were designed to determine the ET of Japanese brome in wheat. The dry weight of Japanese brome with a density of 320 plants $\mathrm{m}^{-2}$ was similar to the 'natural weeds including Japanese brome' treatments and higher than other Japanese brome densities, except for the 640 plants $\mathrm{m}^{-2}$ density which had the highest weed dry weight and yield loss. In the absence of Japanese brome, natural weed infestation was less competitive. The ET of Japanese brome in wheat was between 4 and 5 plants $\mathrm{m}^{-2}$ with $80 \%$ efficiency for the herbicide flucarbazone. It predicted that 4 plants $\mathrm{m}^{-2}$ of Japanese brome can cause $2.11 \%$ to $2.24 \%$ yield losses. This information can contribute to decision making for Japanese brome management. Given several production factors, this ET is more precise and reliable than the ET determined with only yield losses and can be used to develop better control strategies.

Key words: Economic threshold, interference, Japanese brome, Triticum aestivum, weed, wheat.

${ }^{1}$ Shandong Agricultural University, Key Laboratory of Pesticide Toxicology and Application Technique, Shandong Tai' an 271018, PR China. "Corresponding author (wangjx@ sdau.edu.cn).

Received: 12 April 2016.

Accepted: 9 September 2016.

doi:10.4067/S0718-58392016000400007

\section{INTRODUCTION}

Japanese brome (Bromus japonicus Houtt.) is a winter annual weed belonging to the brome family. It is native to Eurasia and commonly found on roadsides, floodplain wetlands, and farmlands such as wheat fields ( $\mathrm{Li}, 1998)$. It has broader ecological amplitude (Li et al., 2015) and is widely distributed in Europe, North Africa, Australasia, north-central Pacific, America, and Asia (Che et al., 2010). Seedlings usually appear in September and October, flowering occurs in early May, and seed dispersal begins in early October (Baskin and Baskin, 1981). A Japanese brome plant can produce 1885 seeds on the average, which can be dispersed by water or wind because they are lightweight (Wang, 1986).

Wheat (Triticum aestivum L.) is widely cultivated in EU-27, China, India, the Russian Federation, USA, Canada, Pakistan, and Ukraine (USDA, 2014). In China, it is the third most important crop in terms of sown area (24.10 million ha) and production (126.00 million $\mathrm{t}$ ). With the changes in farming systems and longterm use of herbicides in recent years, Japanese brome has become extensively distributed and is now found throughout the HuangHuai-Hai Plain of China (Wei, 2010). It heavily infests wheat and is highly competitive with this crop; it can reduce yield by at least $30 \%$ in densely infested fields (Wei, 2010).

With the increasing use of herbicides, the concern about possible effects on the biodiversity and sustainability of natural and agricultural ecosystems has been raised (Andreasen and Andresen, 2011; Andreasen and Stryhn, 2012). Various weed management measures have been used to avoid the unnecessary use of herbicides. One alternative is to reduce herbicide application and only spray over weed areas, but this exceeds the economic threshold (ET) (Gerhards and Christensen, 2003; Christensen et al., 2009; Jeschke et al., 2011; Berge et al., 2012). Another option is to use mechanical control, but the ET is still applicable (Van Der Weide et al., 2008; Datta and Knezevic, 2013).

The ET concept is the fundamental principle of pest/weed population management, which rejects the eradication of pest/weed and supports the regulation of their populations at economically optimum levels (Wilkerson et al., 2002). It is a standard to determine whether a weed management measure is necessary and economical (Hazra et al., 2011; Dodamani and Das, 2013; Das et al., 2014). To be useful, the weed ET is calculated as the weed density at which the cost of control equals the benefits obtained from weed management (Cussans et al., 1986; Cousens, 1987). The ET has currently become the basis of most weed management 
decision models (Wilkerson et al., 2002). The ET-based weed management can significantly contribute to rationalizing herbicide use and reducing herbicide intake from the present levels by decreasing rates (Thomas et al., 2011). Information on the ET would be useful for wheat growers to choose appropriate measures for Japanese brome management.

The impact of different Japanese brome densities in wheat and the minimum density, which could cause economic losses, have never been investigated in China and very little worldwide. Therefore, the objective of this study was to find the degree of interference of Japanese brome for various density levels in wheat and determine its ET.

\section{MATERIALS AND METHODS}

\section{Experimental sites}

Two large-scale wheat field trials were conducted in a commercial field near Tai' an City $\left(35^{\circ} 57^{\prime} \mathrm{N}, 117^{\circ} 3^{\prime} \mathrm{E}\right)$, Shandong Province, China, which was infested with Japanese brome. The studies were established during 2013 and 2014, respectively. The soil at the experimental site was a silt loam (Semi-Alfisols-Cinnamon soils) consisting of $38 \%$ sand, $61 \%$ silt, and $1 \%$ clay with organic matter content of $21.4 \mathrm{~g} \mathrm{~kg}^{-1}$ soil and $\mathrm{pH} 7.1$. During the $3-\mathrm{yr}$ experimentation, a cropping system with wheat (OctoberJune) and corn (June-October) was used.

\section{Treatments, plant sampling, and observations}

Treatments consisted of eleven infestation levels of Japanese brome (JB) or weeds, which included nine JB pure stand densities $\left(0,5,10,20,40,80,160,320\right.$, and 640 plants $\left.\mathrm{m}^{-2}\right)$ and two natural weed infestations including JB (UWC) and excluding JB (UWC-JB) (Table 1). The UWC and UWCJB treatments were used to compare the interference of $\mathrm{JB}$ in pure stand densities with natural infestations with or without JB.

Information on JB density effect in wheat is scarce both in China and other countries; densities were arbitrarily chosen for their growth vigor in wheat fields. Treatments were laid out in a randomized complete block design with four replicates.

The required JB densities were maintained beginning at $20 \mathrm{~d}$ after sowing (DAS) the wheat by periodical counting and manually eliminating redundant weeds (Table 2). Weedfree controls (WFC) were managed throughout the crop growing period by manual weeding beginning at 10 DAS. The gross and net (i.e., actually harvested area) plot sizes were $2.0 \mathrm{~m} \times 1.5 \mathrm{~m}$ and $1.0 \mathrm{~m} \times 1.0 \mathrm{~m}$, respectively. Wheat was harvested on 4 June and 10 June in 2013-2014 and 2014-2015, respectively.

Plant sampling and observations to assess weed infestation consisted of a quadrat $(0.5 \mathrm{~m} \times 0.5 \mathrm{~m})$ that was randomly placed in each plot in which all the weeds were collected at 60 DAS and sun-dried for $2 \mathrm{~d}$. Samples were then placed in an electric oven at $70{ }^{\circ} \mathrm{C}$ for $48 \mathrm{~h}$ and dry weight (DW) was recorded. At maturity, all the wheat from each treatment was harvested and threshed. Grains were then cleaned and yield was recorded. The observed yield losses (\%) across treatments compared to weed-free control were calculated using Equation 1 (Das, 2008):

$$
\text { Yield loss }=\left[\left(Y_{w f}-Y_{t}\right) * 100\right] / Y_{w f}
$$

where $Y_{w f}$ and $Y_{t}$ are wheat yields in weed-free control and treatment, respectively.

Table 1. Treatments adopted in the experiment.

\begin{tabular}{|c|c|c|}
\hline $\begin{array}{l}\text { Japanese brome (JB) or } \\
\text { weed infestation level }\end{array}$ & Treatment description & $\begin{array}{l}\text { Treatment } \\
\text { code }\end{array}$ \\
\hline JB 0 plant $\mathrm{m}^{-2}$ or weed-free control (WFC) & Free from all weeds including JB through periodic manual weeding & JB $0 / \mathrm{WFC}$ \\
\hline JB 5 plants $\mathrm{m}^{-2}$ & & JB 5 \\
\hline JB 10 plants $\mathrm{m}^{-2}$ & & JB 10 \\
\hline JB 20 plants $\mathrm{m}^{-2}$ & No other weeds except JB were present; manual weeding of other weeds and excess Japanese & JB 20 \\
\hline JB 40 plants $\mathrm{m}^{-2}$ & brome population to maintain the required JB density from 20 DAS onward & JB 40 \\
\hline JB 80 plants $\mathrm{m}^{-2}$ & & JB 80 \\
\hline JB 160 plants $\mathrm{m}^{-2}$ & & JB 160 \\
\hline JB 320 plants $\mathrm{m}^{-2}$ & & JB 320 \\
\hline JB 640 plants $\mathrm{m}^{-2}$ & & JB 640 \\
\hline All weeds including JB & Natural weed infestation of all weeds, unweeded control & UWC \\
\hline All weeds excluding JB & Natural weed infestation without JB & UWC-JB \\
\hline
\end{tabular}

Table 2. Natural weed growth at $20 \mathrm{~d}$ after sowing (DAS) wheat for all weeds including Japanese brome (UWC).

\begin{tabular}{|c|c|c|c|}
\hline \multirow[b]{2}{*}{ Botanical name of weed } & \multirow[b]{2}{*}{ Common name of weed } & \multicolumn{2}{|c|}{ Weed growth in UWC } \\
\hline & & Weed density ${ }^{\mathrm{a}}$ & Weed dry weight $\mathrm{t}^{\mathrm{a}}$ \\
\hline & & $\mathrm{nr} \mathrm{m}^{-2}$ & $\mathrm{~g} \mathrm{~m}^{-2}$ \\
\hline Bromus japonicus Houtt. & Japanese brome & $114 \pm 8.2$ & $3.42 \pm 0.15$ \\
\hline Phleum paniculatum Huds. & British timothy & $89 \pm 6.8$ & $3.56 \pm 0.21$ \\
\hline Capsella bursa-pastoris (L.) Medik. & Shepherd's-purse & $64 \pm 4.1$ & $2.13 \pm 0.13$ \\
\hline Stellaria media (L.) Vill. & Common chickweed & $28 \pm 3.8$ & $0.54 \pm 0.14$ \\
\hline Alopecurus aequalis Sobol. & Short-awn Foxtail & $17 \pm 1.6$ & $0.25 \pm 0.06$ \\
\hline Galium aparine $\mathrm{L}$. & Catchweed & $11 \pm 2.3$ & $0.21 \pm 0.08$ \\
\hline Total weeds & & 323 & 10.11 \\
\hline
\end{tabular}

${ }^{\mathrm{a}}$ Mean $( \pm \mathrm{SD})$ weed data of eight [four replicates $\times 2$ yr $(2013$ and 2014$)$ ] quadrats (each with $0.5 \times 0.5 \mathrm{~m}$ area). 


\section{Simulation of wheat yield and yield loss}

A rectangular hyperbolic model (Equation 2) (Cousens, 1985) was used to simulate wheat yields $(Y)$ across JB densities (d).

$$
Y=Y_{w f}[1-i d / 100(1+i d / A)]
$$

where $Y$ is simulated wheat yield at $d$ weed density, $Y_{w f}$ is weed-free crop yield, $i$ is percentage yield loss per unit weed density $(d)$ as $d \rightarrow 0$, and $A$ is the asymptotic value of the maximum yield loss (\%) as $d \rightarrow \infty$.

Natural weed infestations UWC and UWC-JB did not have a fixed JB density. Therefore, they were not considered in the simulation of wheat yield and yield losses (using Equation 2), in the study of correlations between observed and simulated yields and yield losses, and in the analysis of wheat yield and JB density.

\section{Determination of Japanese brome economic threshold}

The ET of JB (Cousens, 1987) was determined using the following quadratic equation (Equation 3$)$.

$$
1+(i / A)[2-H-(Y P A H / C)] T+(i / A)^{2}(1-H) T^{2}=0
$$

where $i$ and $A$ are defined above, $Y$ is weed-free wheat yield, $P$ is the unit price of wheat grain (i.e., minimum support price by the Government of China), $H$ is the efficiency of herbicide flucarbazone (4,5-dihydro-3-methoxy-4-methyl5-oxo- $N$-(2-trifluoromethoxyphenylsulfonyl)- $1 \mathrm{H}$-1,2,4triazole-1-carboxamide), $C$ is the cost of JB control (i.e., cost of flucarbazone and its application), and $T$ is economic threshold density.

Flucarbazone is highly effective against JB and selective to wheat (Gao et al., 2011). It was applied at $0.0315 \mathrm{~kg} \mathrm{ha}^{-1}$ 20 DAS in $450 \mathrm{~L}$ water with a knapsack sprayer fitted with a flat fan nozzle; wheat was grown in four extra plots to determine JB control efficiency $(\mathrm{H})$, which was required to determine the ET of JB in wheat.

\section{Statistical analysis}

Wheat and JB/weeds data were analyzed by the ANOVA technique for a randomized complete block design. The JB/ weeds DW data were subjected to a square root transformation before performing ANOVA. Significance was tested by the variance ratio (i.e., $\mathrm{F}$ value) at $\mathrm{P} \leq 0.05$ (Gomez and Gomez, 1984). Standard error of difference between means (SE) was calculated for each of the studied JB/weeds and wheat variables to compare treatment means. Curve estimation was performed to determine the relationship between JB densities and wheat yield with SPSS version 17.0 (IBM, Armonk, New York, USA). Correlation coefficients between observed yields and simulated equations were calculated to obtain a logical conclusion of the simulated data.

\section{RESULTS}

\section{Growth of Japanese brome/weeds}

Natural weed infestation in wheat (Table 2) included six weed species, namely, Japanese brome (Bromus japonicus
Houtt.), common chickweed (Stellaria media [L.] Vill.), British timothy (Phleum paniculatum Huds.), shepherd'spurse (Capsella bursa-pastoris [L.] Medik.), short-awn foxtail (Alopecurus aequalis Sobol.), and catchweed (Galium aparine L.) Among these (UWC), JB exhibited the highest density of $114 \pm 4.2$ plants $\mathrm{m}^{-2}$ and $35.3 \%$ of the total weed population, which accumulated a DW of $3.42 \pm$ $0.45 \mathrm{~g} \mathrm{~m}^{-2}$ (Table 2).

Increasing JB density from JB 5 to JB 640 resulted in a significant increase in its DW (Figures 1a and 1b). For any one particular density, DW was much higher than at lower densities and much lower than at the higher densities. Total weed DW was higher in JB 640 followed by JB 320 and UWC with values not differing among them.

\section{Wheat growth and yield}

Wheat yield differed significantly across years and treatments. All the JB densities resulted in a significant reduction in wheat spike number (Table 3 , Figure $2 \mathrm{a}$ ) in both years compared to the weed-free control (WFC). The trend was similar in the 2-yr wheat yields (Table 3, Figure 2b). Of all JB densities, JB 640 caused the greatest reduction in these variables.

Figure 1. Japanese brome/weed dry weight in different Japanese brome/weed infestation levels in 2013 (a) and 2014 (b).
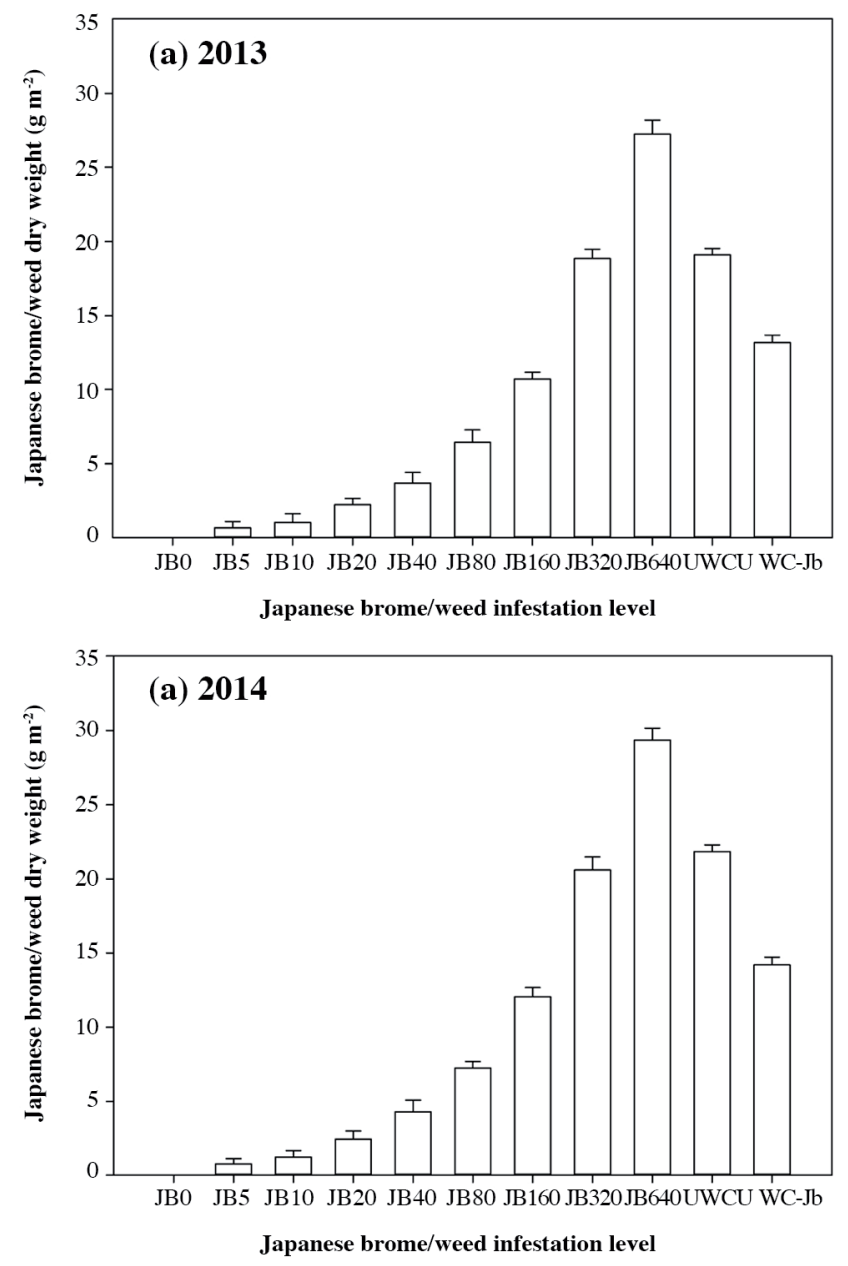

Vertical bars represent standard errors of the means. 
Table 3. Wheat spike number and wheat yields across treatments and years.

\begin{tabular}{|c|c|c|c|c|}
\hline \multirow[b]{2}{*}{ Treatment } & \multicolumn{2}{|c|}{ Spike } & \multicolumn{2}{|c|}{ Wheat yield } \\
\hline & 2013 & 2014 & 2013 & 2014 \\
\hline & \multicolumn{2}{|c|}{$-\mathrm{nr} \mathrm{m}^{-2}$} & \multicolumn{2}{|c|}{$-\mathrm{tha}^{-1}$} \\
\hline JB 0 & $566 \mathrm{a}$ & $550 \mathrm{a}$ & $7.585 \mathrm{a}$ & $7.367 \mathrm{a}$ \\
\hline JB 5 & $538 b$ & $523 b$ & $7.170 \mathrm{~b}$ & $6.960 \mathrm{~b}$ \\
\hline JB 10 & $517 \mathrm{c}$ & $498 c$ & $6.955 \mathrm{c}$ & $6.743 \mathrm{c}$ \\
\hline JB 20 & $488 \mathrm{~d}$ & $481 d$ & $6.675 d$ & $6.517 d$ \\
\hline JB 40 & $481 d$ & $468 \mathrm{de}$ & $6.468 \mathrm{e}$ & $6.330 \mathrm{e}$ \\
\hline JB 80 & $460 \mathrm{e}$ & $454 \mathrm{e}$ & $6.223 \mathrm{f}$ & $6.117 \mathrm{f}$ \\
\hline JB 160 & $427 f$ & $427 f$ & $5.945 \mathrm{~g}$ & $5.617 \mathrm{~g}$ \\
\hline JB 320 & $399 \mathrm{~g}$ & $411 \mathrm{fg}$ & $5.363 \mathrm{i}$ & $5.260 \mathrm{i}$ \\
\hline JB 640 & $355 \mathrm{i}$ & $363 \mathrm{~h}$ & $4.693 \mathrm{j}$ & $4.767 \mathrm{k}$ \\
\hline UWC & 379h & $398 \mathrm{~g}$ & $5.190 \mathrm{i}$ & $5.127 j$ \\
\hline UWC-JB & $415 f g$ & $419 \mathrm{f}$ & $5.570 \mathrm{~h}$ & $5.440 \mathrm{~h}$ \\
\hline
\end{tabular}

JB: Japanese brome, UWC: natural weed infestations including JB, UWC-JB natural weed infestations excluding JB.

Figure 2. Relationship between Japanese brome densities and wheat spike number and wheat grain yield for 2013 and 2014.
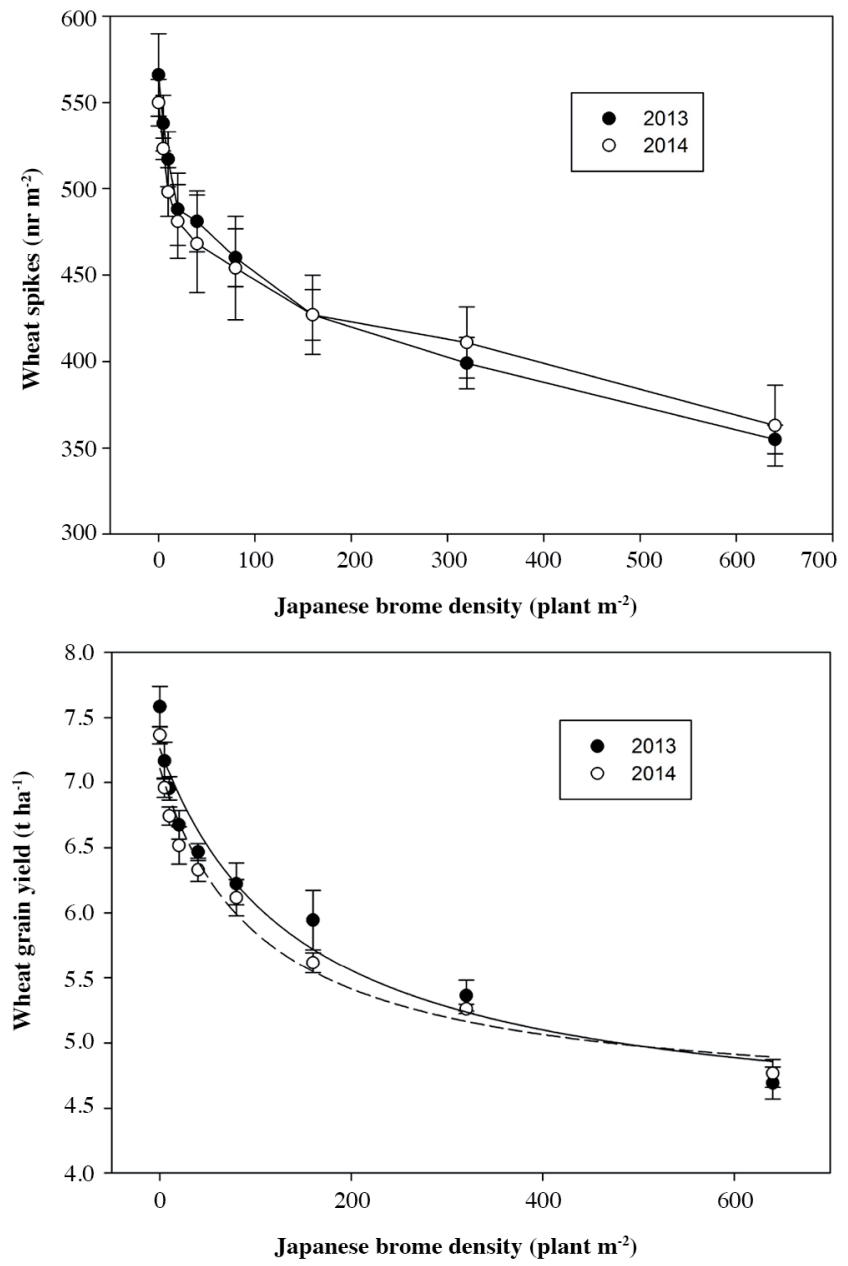

Vertical bars represent standard errors of the means.

These treatments reduced spike number and yearly yield in both years and were comparable to 'all weed including JB (UWC)', which caused the highest reduction and ranked second behind JB 640 (Table 3).

Wheat yield and JB density were inversely related, and there was a significant yield decrease with increasing JB density in both years (Figure $2 b$ ).

\section{Simulation of yield and yield loss and} economic threshold

The simulation equations for wheat yields across the years were $\mathrm{Y}=7.585\{1-[0.558 \mathrm{~d} / 100(1+0.558 \mathrm{~d} / 37.197)]\}$ and $\mathrm{Y}=7.367\{1-[0.599 \mathrm{~d} / 100(1+0.599 \mathrm{~d} / 35.084)]\}$. The simulation equations of yield loss were $\mathrm{Y}_{\mathrm{L}}=0.558 \mathrm{~d} / 100(1$ $+0.558 \mathrm{~d} / 37.197)$ and $Y_{L}=0.599 \mathrm{~d} / 100(1+0.599 \mathrm{~d} / 35.084)$ during the first and second years.

On the whole, observed yields and simulated equations (Table 4) were better correlated $\left(\mathrm{R}^{2}=0.929\right.$ and 0.951 in 2013 and 2014, respectively) leading to small differences between observed and simulated yields (Figure 3 ).

The ET of JB was 5 and 4 plants $\mathrm{m}^{-2}$ during first and second years, respectively (Table 5) and the equation for ET was $0.000045 \mathrm{~T}^{2}-0.204 \mathrm{~T}+1=0 ; 0.0000578 \mathrm{~T}^{2}$ $0.2322 \mathrm{~T}+1=0$.

Table 4. Simulation equations of wheat yields and yield loss.

\begin{tabular}{lcc}
\hline Parameters & 2013 & 2014 \\
\hline$i$ & $0.558 \pm 0.139$ & $0.599 \pm 0.124$ \\
$A$ & $37.197 \pm 3.682$ & $35.084 \pm 2.749$ \\
$R^{2}$ & 0.929 & 0.951 \\
\hline
\end{tabular}

$i$ : Percent yield loss per unit of weed density, $A$ : asymptotic value of the maximum yield loss $(\%)$.

$R^{2}=1$ - (residual sum of squares)/(corrected sum of squares).

Figure 3. Observed and simulated yield losses (\%) of wheat for Japanese brome densities in 2013 (a) and 2014 (b).
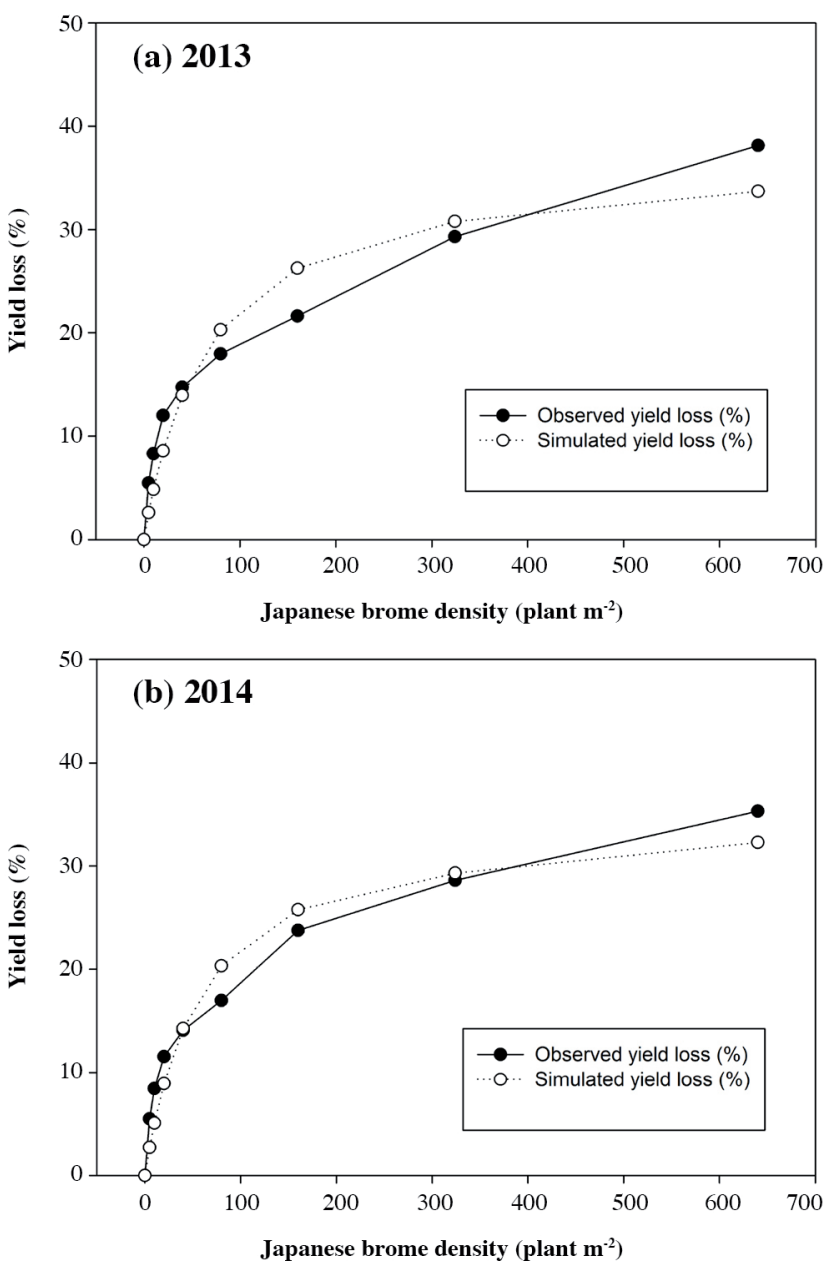
Table 5. Simulation of economic threshold level of Japanese brome in wheat.

\begin{tabular}{|c|c|c|}
\hline Parameters & 2013 & 2014 \\
\hline$Y$ (observed weed-free yield), $\mathrm{t} \mathrm{ha}^{-1}$ & 7.585 & 7.367 \\
\hline$i, \%$ & 0.558 & 0.599 \\
\hline$A, \%$ & 37.197 & 35.084 \\
\hline$C$ (cost of control with flucarbazone at $\left.31.5 \mathrm{~g} \mathrm{ha}^{-1}\right), \mathrm{CNY} \mathrm{ha}^{-1(\mathrm{a})}$ & 320 & 320 \\
\hline$H$ (flucarbazone efficiency), \% & 80 & 80 \\
\hline 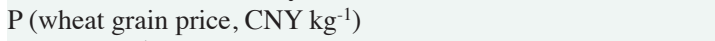 & 2.1 & 2.3 \\
\hline ET equation ${ }^{b}$ & $0.000045 \mathrm{~T}^{2}-0.204 \mathrm{~T}+1=0$ & $0.0000578 \mathrm{~T}^{2}-0.2322 \mathrm{~T}+1=0$ \\
\hline$T$ (economic threshold level) & $4.9(\sim 5.0)$ & $4.3(\sim 4.0)$ \\
\hline$R^{2}$ & 0.929 & 0.951 \\
\hline
\end{tabular}

${ }^{\mathrm{a}} 1 \mathrm{US} \$=6.38 \mathrm{CNY}$ (approx.)

${ }^{\mathrm{b}}$ Derived from Equation $1+(i / A)[2-H-(Y P A H / C)] T+(i / A)^{2}(1-H) T^{2}=0$ using the values of parameters mentioned in this Table.

$Y$ : Simulated wheat yield, $i$ : percent yield loss per unit of weed density, $A$ : asymptotic value of maximum yield loss $(\%)$.

\section{DISCUSSION}

\section{Density effect on Japanese brome and weed interference}

Japanese brome is naturalized in the wheat microclimate. It has numerous tillers and high fertility. A large seed bank of this weed exists in the soil and this leads to continual germination under favorable moisture and temperature conditions (Wang, 1986; Li et al., 2015). These factors might be responsible for its dominance over other weeds in wheat (Table 1) in the present study.

The degree of weed interference is highly related to the weed species, population, and its DW, which is finally reflected in crop yield (Das and Yaduraju, 1999). Yield losses are generally proportional to the sum total of water, light, and nutrients that weeds use when competing with the crop (Zimdahl, 2004). The present study exhibited an evident level of interference.

The density effect of JB on wheat spike number and yield in the present study were significantly reduced at the lowest JB 5 density (Table 3 ). The order of negative effect of the treatments on the 2-yr mean yield was JB $640>$ UWC $>$ JB $320>$ UWC-JB > JB $160>$ JB $80>$ JB $40>$ JB $20>$ JB $10>\mathrm{JB} 5$. The increasing density resulted in an obvious development of DW in JB. The order of competitiveness based on the 2-yr mean DW accumulated by weeds/JB was JB $640>$ UWC > JB $320>$ UWC-JB > JB $160>$ JB $80>$ JB $40>$ JB $20>$ JB $10>$ JB 5 .

The highest density, JB640, exhibited the most serious negative effect with the highest JB DW and the highest yield loss. The pure stand density of JB 320 caused a yield loss similar to that of natural weed infestation (UWC). Weed biomass in these two treatments were almost equal (Figures 1a and 1b) and weed traits were probably sufficiently similar for the mixed population to act as a pure stand of JB with the same biomass.

As a result of the high population in UWC, intercompetitiveness between six weed species and intracompetitiveness between JB plants might have reduced overall interference (Cousens, 1985, 1987). This confirms the fact that moderate weed infestation can be as serious as heavy infestation (Das, 2008). In addition, the increase in the DW of JB was not as proportional as the increase in its density. Density increased 128 times (from 5 to 640 JB plants $\mathrm{m}^{-2}$ ), but the increase in DW (Figure 1) was only approximately fortyfold. The intraspecific and interspecific competition at higher densities might be responsible for reduced individual DW (Zimdahl, 2004; Das, 2008).

Natural weed infestation without JB (UWC-JB) caused less interference and was inferior to UWC, JB 320, and JB 640 based on yield loss. The reason could be that total weed population was less than in these treatments (Table 2). The seeds of JB are always maturity in June in accordance with wheat which is later than other weeds for a long time (Baskin and Baskin, 1981). This consistent growth leads JB to compete with wheat for a longer period of time up to wheat maturity.

\section{Simulation of yield and yield loss and economic threshold}

The crop yield-density model is widely used (Cousens, 1985), and weed density can easily be calculated by farmers.

The ET indicates the weed density at which the economic advantage of the treatment is in equilibrium with the cost of weed management. To confirm whether weed control measures are necessary, weed interference in a crop should be predicted as soon as possible (Hazra et al., 2011). The ET provides baseline information to make weed control decisions based on economics (Cousens, 1987), and it plays an important role in establishing an integrated weed management program (Wilkerson et al., 2002).

We observed that the ET of JB varied from 4 to 5 plants $\mathrm{m}^{-2}$ across both years (Table 5). Such a variation in ET can be due to the changes in crop and weed growth and crop price (Fischer et al., 2004; Cheema and Akhtar, 2006; Hazra et al., 2011; Dodamani and Das, 2013; Das et al., 2014).

Currently, yield loss in most ET determinations was the sole criterion. Based on yield losses, an ET of 6-7 Phalaris minor Retz. plants $\mathrm{m}^{-2}$ (Hussain et al., 2015), 7-12 Avena sterilis L. plants $\mathrm{m}^{-2}, 25-35$ Lolium multiflorum Lam. plants $\mathrm{m}^{-2}$, and less than 40 Bromus sterilis L. plants $\mathrm{m}^{-2}$ (Zanin et al., 1993) have been reported in wheat.

In contrast, the present study adopted a quadratic equation (Equation 3) that took into account several factors to determine the ET, such as yield, crop price, herbicide efficiency, and weed control cost (Cousens, 1987). 
Therefore, this method might be more reliable and rational because the abovementioned factors affect the ET (Cheema and Akhtar, 2006).

The ET is generally based on the profits and losses of the current year. Certain benefits accruing from ET are not considered. The benefits for subsequent years of the adopted herbicide and management measures, which might affect future weed populations by reducing their seed bank in the soil, are also ignored (Cussans et al., 1986; Norris, 1992). These benefits are not easily quantified, but including them can make ET more useful.

The 2-yr ET mean (Table 5) in the present study was $4.5\left(\sim 4\right.$ plants $\left.\mathrm{m}^{-2}\right)$. Considering that $5.47 \%$ and $5.52 \%$ yield losses in the first and second years, respectively, at JB 5 plants $\mathrm{m}^{-2}$ (Figures $3 \mathrm{a}$ and $3 \mathrm{~b}$ ), the yield loss would be $2.11 \%$ to $2.24 \%$ at JB 4 plants $\mathrm{m}^{-2}$. This explains why even a $2 \%$ yield loss is an economic loss in this situation. This is mainly because of the high cost of herbicide performance and high wheat price. Wheat benefited from government price support and flucarbazone has an almost fixed price throughout China. Therefore, ET could be very useful in other parts of China.

\section{CONCLUSIONS}

In summary, our results show that a pure stand of Japanese brome (JB) with 320 plants $\mathrm{m}^{-2}$ was as competitive as natural weed infestation including JB. They both caused a consistent interference in wheat. The economic threshold (ET) was between 4 and $5 \mathrm{JB}$ plants $\mathrm{m}^{-2}$, considering a postemergence treatment of flucarbazone with $80 \%$ efficiency. This information would be useful to make JB control decisions and play an important role in establishing an integrated management program.

Overall, taking into account several factors, the ET would be more economical and helpful. Using this ET to control JB would reduce future weed populations, rationalize herbicide use, and lead to the development of better control strategies.

\section{ACKNOWLEDGEMENTS}

This work was financially supported by the Special Fund for Agro scientific Research in the Public Interest of China (201303022) and National Natural Science Foundation of China (31471787). The authors thank all the workers for their assistance in this research.

\section{REFERENCES}

Andreasen, C., and L.C. Andresen. 2011. Managing farmland flora to promote biodiversity in Europe. CAB Reviews: Perspectives in Agriculture, Veterinary Science, Nutrition and Natural Resources. 6:1-11. doi:10.1079/PAVSNNR20116047.

Andreasen, C., and H. Stryhn. 2012. Increasing weed flora in Danish beet, pea and winter barley fields. Crop Protection 36:11-17. doi:10.1016/j.cropro.2012.01.012.
Baskin, J.M., and C.C. Baskin. 1981. Ecology of germination and flowering in the weedy winter annual grass Bromus japonicus. Journal of Range Management 34:369-372. doi: $10.2307 / 3897906$.

Berge, T.W., S. Goldberg, K. Kaspersen, and J. Netland. 2012. Towards machine vision based site-specific weed management in cereals. Computers and Electronics in Agriculture 81:79-86. doi:10.1016/j.compag.2011.11.004.

Cousens, R. 1985. An empirical model relating crop yield to weed and crop density and a statistical comparison with other models. The Journal of Agricultural Science 105:513-521. https://doi. org/10.1017/S0021859600059396.

Cousens, R. 1987. Theory and reality of weed control thresholds. Plant Protection Quarterly 2:13-20.

Cussans, G.W., R.D. Cousens, and B.J. Wilson. 1986. Thresholds for weed control - The concepts and their interpretation. p. 253-260. In Proceedings of $5^{\text {th }}$ European Weed Research Society (EWRS) Symposium on Economic Weed Control, Stuttgart-Hohenheim. European Weed Research Society, Doorwerth, The Netherlands.

Che, J.D., Z.Q. Yuan, D.H. Jin, Y.M. Wang, G.W. Zhang, X.G. Hu, et al. 2010. Study report of Bromus japonicus Thunb. Biological characteristics. Beijing Agriculture 36:41-43.

Cheema, M.S., and M. Akhtar. 2006. Evaluation of economic threshold level of wild oat (Avena fatua L.) in wheat under superimposed application of fenoxaprop-p-ethyl. Pakistan Journal of Weed Science Research 12:257-264.

Christensen, S., H.T. Sogaard, P. Kudsk, M. Norremark, I. Lund, E.S. Nadimi, et al. 2009. Site-specific weed control technologies. Weed Research 49:233-241. doi:10.1111/j.13653180.2009.00696.x.

Das, T.K. 2008. Weed science: basics and applications. 901 p. Jain Brothers Publishers, New Delhi, India.

Das, T.K., A.K. Paul, and N.T. Yaduraju. 2014. Density-effect and economic threshold of purple nutsedge (Cyperus rotundus) in soybean. Journal of Pest Science 87:211-220. doi:10.1007/ s10340-013-0536-4.

Das, T.K., and N.T. Yaduraju. 1999. Effect of weed competition on the growth, nutrient uptake and yield of wheat as affected by irrigation and fertilizers. Journal of Agricultural Science 133:45-51.

Datta, A., and S.Z. Knezevic. 2013. Flaming as an alternative weed control method for conventional and organic agronomic crop production systems: a review. Advances in Agronomy 118:399-428.

Dodamani, B.M., and T.K. Das. 2013. Density and nitrogen effects on interference and economic threshold of common lambsquarters in wheat. Journal of Pest Science 86:611-619. doi:10.1007/s10340-013-0478-x.

Fischer, D.W., R.G. Harvey, T.T. Bauman, S. Phillips, S.C. Hart, A.J. Gregg, et al. 2004. Common lambsquarters (Chenopodium album) interference with corn across the north central United States. Weed Science 52:1034-1038. doi:http://dx.doi. org/10.1614/P2000-172.

Gao, X.X., M. Li, Q.L. Ge, J.H. Zhang, Z.J. Gao, and Y.L. Zhang. 2011. Biological activity of eight herbicides to eight species of major grasses in wheat fields. Acta Phytophylacica Sinica 38:557-562.

Gerhards, R., and S. Christensen. 2003. Real-time weed detection, decision making and patch spraying in maize, sugarbeet, winter wheat and winter barley. Weed Research 43:385-392. doi:10.1046/j.1365-3180.2003.00349.x.

Gomez, A.K., and A.A. Gomez. 1984. Statistical procedures for agricultural research. $2^{\text {nd }}$ ed. Wiley InterScience, New York, USA. 
Hazra, D., T.K. Das, and N.T. Yaduraju. 2011. Interference and economic threshold of horse purslane (Trianthema portulacastrum L.) in soybean cultivation in northern India. Weed Biology and Management 11:72-82. doi:10.1111/j.14456664.2011.00408.x

Hussain, S., A. Khaliq, A. Matloob, S. Fahad, and A. Tanveer. 2015. Interference and economic threshold level of little seed canary grass in wheat under different sowing times. Environmental Science and Pollution Research 22:441-449. doi:10.1007/s 11356-014-3304-y.

Jeschke, M.R., D.E. Stoltenberg, G.O. Kegode, C.L. Sprague, S.Z. Knezevic, S.M. Hock, et al. 2011. Predicted soybean yield loss as affected by emergence time of mixed-species weed communities. Weed Science 59:416-423. http://dx.doi. org/10.1614/WS-D-10-00129.1.

Li, Y.H. 1998. Weeds of China. Volume 2. Weeds of seed plants. p. 1180-1181. China Agriculture Press, Beijing, China.

Li, Q., J.N. Tan, W. Li, G.H. Yuan, L. Du, S. Ma, et al. 2015. Effects of environmental factors on seed germination and emergence of Japanese brome (Bromus japonicus). Weed Science 63:641-646. http://dx.doi.org/10.1614/WS-D-1400131.1.

Norris, R.F. 1992. Case history for weed competition/population ecology. Barnyard grass (Echinochloa crusgalli) in sugarbeet (Beta vulgaris). Weed Technology 6:220-227.

Thomas, A.G., A. Legere, J.Y. Leeson, F.C. Stevenson, F.A. Holm, and B. Gradin. 2011. Weed community response to contrasting integrated weed management systems for cool dryland annual crops. Weed Research 51:41-50. doi:10.1111/j.13653180.2010.00821.x.
USDA. 2014. China wheat production by year (1000 metric tonnes). United States Department of Agriculture (USDA), Washington D.C., USA. Available at http://www.indexmundi. com/agriculture/?country $=$ cnandcommodity $=$ wheatandgraph =production (accessed 15 December 2014).

Van Der Weide, R.Y., P.O. Bleeker, V.T.J.M. Achten, L.A.P. Lotz, F. Fogelberg, and B. Melander. 2008. Innovation in mechanical weed control in crop rows. Weed Research 48:215-224. doi:10.1111/j.1365-3180.2008.00629.x.

Wang, M.F. 1986. Occurrence, spread and control of Japanese brome in the wheat. Weed Science 2:3-5.

Wei, M. 2010. Biological characteristics of Japanese brome observed in the wheat of Zhuanglang country. Gansu Agricultural Science Technology 8:30-31.

Wilkerson, G.G., L.J. Wiles, and A.C. Bennett. 2002. Weed management decision models: pitfalls, perceptions, and possibilities of the economic threshold approach. Weed Science 50:411-424. http://dx.doi.org/10.1614/00431745(2002)050[0411:WMDMPP]2.0.CO;2.

Zanin, G., A. Berti, and L. Toniolo. 1993. Estimation of economic thresholds for weed control in winter wheat. Weed Research 33:459-467. doi:10.1111/j.1365-3180.1993.tb01962.x.

Zimdahl, R.L. 2004. Weed-crop competition: A review. $2^{\text {nd }}$ ed. Blackwell Publishing, Ames, Iowa, USA. 